\title{
Tribute to Professor John Webster (1925-2014)
}

\author{
E. B. Gareth Jones ${ }^{1} \cdot$ Kevin D. Hyde ${ }^{2}$
}

Published online: 9 November 2015

(C) School of Science 2015

This isssue of Fungal Diversity is dedicated to the memory of John Webster and his various contributions to mycology: an outstanding teacher and researcher, as the author of the acclaimed book Introduction to Fungi (now in its 3rd edition), the production of many films to illustrate the growth and reproduction of fungi, as President of the British Mycological Society $(1969,1996$ the centenary year of the BMS), for the M.Sc. course in plant pathology and the garden of plant pathogens at Exeter, as President of the International Mycological Association (IMA) 1983-1990, for his many contributions on coprophilous and aquatic fungi and for his organising skills as the General Secretary of the 1st International Mycological Congress hosted in Exeter in 1971. In essence, his work and life impinged on every aspect of mycology for some six decades, resulting in the publication of many noteworthy scientific papers.

John Webster was an enthusiastic field mycologist, leading many local fungal forays that yielded a wide range of taxa for his teaching and research. He knew exactly where to go to collect specific fungi, such as sending EBG Jones fresh samples of Cordycepes militaris for his research work in Thailand. He advanced the study of aquatic fungi by

E. B. Gareth Jones

torperadgj@gmail.com

Kevin D. Hyde

kdhyde3@gmail.com

1 Department of Botany and Microbiology, King Saudi University, Riyadh, Saudi Arabia

2 Center of Excellence in Fungal Research, Mae Fah Luang University, Chiang Rai 57100, Thailand

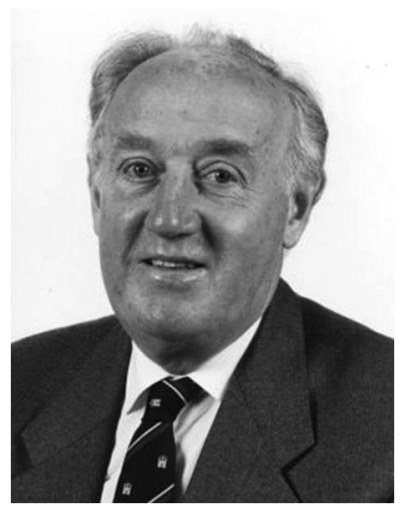

isolating and inducing sporulation, thus enabling the classification of many asexual morphs. He would have been particularly excited with the progress made in the classification of the "Ingoldian" fungi with the advancement in molecular studies. These field trips also enabled him to make fresh drawings and photographs for his classical book "Introduction to Fungi" He came to Portsmouth for a week to learn about marine fungi so that he had first-hand knowledge of the group for inclusion in his forthcoming book. He was particularly interested in the ascomata of Corollospora maritima and its attachment to sand grains. His other major contribution was on ballistospore discharge and elucidating the mechanism behind the launching of basidiospores into the air.

He was the supervisor of many Ph.D. students, many staying in mycology and making significant contributions to the subject: Drs. Enrique Descals, Clare Robinson, Professors Lynne Body, Nik Money, Alan Rayner and Naresh Magan.

John was an excellent organizer, as demonstrated by the organization of the 1st International Mycological Congress in 
Exeter in 1971. No detail was left unattended and forged the ground for the immense success of this congress world-wide for the following decades, with the 10th Congress in Thailand in 2014. The same efficiency and energy was displayed in his various roles as President of the BMS and the IMA, always promoting the advancement of mycology.
John was always forthright, always accommodating, always welcoming, and with a particular sense of humour, and enjoyed musical activities. He was devoted to his wife Brom (who predeceased him) and his family. Above all, he was one of mycology's greats, whose many contributions will be a lasting testimony. 